\title{
Energy, Energetics and Energy Policy
}

ISSN Print: 2576-0556

\author{
Siniša Franjić \\ Independent Researcher, Croatia.
}

How to cite this paper: Siniša Franjić. (2020) Energy, Energetics and Energy Policy. Journal of Humanities, Arts and Social Science, 4(2), 187-193.

DOI: $10.26855 /$ jhass.2020.07.012

Received: November 6, 2020

Accepted: November 30, 2020

Published: December 25, 2020

*Corresponding author: Siniša Franjić, Independent Researcher, Croatia.

Email: sinisa.franjic@gmail.com

\begin{abstract}
Energy is one of the key global issues of economic development and human survival. The process of globalization has created a strong impulse to increase the production and consumption of products and services in the world. Accelerated development still requires an adequate resource base which is limited. Energy policy represents the way in which a particular entity decides to address energy development issues, including energy production, distribution and consumption. Features of energy policy may include legislation, international treaties, investment incentives, energy conservation guidelines, taxation, and other public policy techniques. The energy sector is, in the production sense, one of the most important factors of any modern society. Given that it forms energy forms that have different phases of production and distribution to the final consumer, the energy sector has become an area which needs to be legally regulated. The main goal in planning the energy development of each country is to create such an energy system that would be independent of energy imports and have minimal costs and losses in production, conversion, transmission, distribution and transportation.
\end{abstract}

\section{Keywords}

Energy, Energetics, Energy Policy, Energy Law

\section{Introduction}

The development of the European Energy Policy was at the very center of the attention of the European project, apropos the project of the then known European Community, and today the European Union, which was first established in 1951. By the European Coal and Steel Community, and in 1957, and the European Atomic Energy Community. From then on to today, energy has remained one of the key strategic and security issues in the world.

Increasing energy dependence on imports and limited successes in diversification, high and changing energy prices, rising demand, security risks associated with transport routes, climate change, the need for energy market liberalization, limited coordination of energy policy factors that hinder investment in energy infrastructure and difficulties in the oil and gas market are just some of the important issues that the European Union faced with, and the same led to the need to create a common European energy strategy.

The European Energy Policy (Energy Policy for Europe-EPE) was launched by the decision of the Heads of EU Member States in 2007. European energy policy aims at achieving three goals: greater security of supply, ensuring competitiveness of European economies and availability of energy, and promoting environmental sustainability and combating against climate changes. This effectively enables energy supply, integration of energy markets into the European Union, ensuring energy policy alignment with the goals of sustainable development through rational use of energy and the development of renewable sources, and promoting research and technological development in energy. European Energy Policy includes the use of coal, oil, gas, electricity, new and renewable energy sources and nuclear energy and demand management for different forms of energy. 


\section{Energy}

Humankind has always needed energy, and while the source and usage of energy have changed over time some patterns have remained constant (Coyle et al., 2014). In earlier times, food was the key source of energy for people and their livestock. This form of energy not only allowed our race to survive but dictated in part how civilization developed. Societies worldwide focused on developing new and sustainable food sources. The storage of food and its distribution was a factor in how groups learned to organize themselves communally, best survive periods of shortage, and also benefit from occasional abundances. The discovery of methods of processing and preserving food meant that new sources of food could be used with increased efficiency and increasingly less waste. People migrated across continents, seas, and oceans in response to sometimes complex social pressures, but certainly the search for food and reliable sources of food was a common factor in their movements. There may be a greater urgency today than heretofore to identifying sustainable sources of energy, increasing the efficiency of energy usage, and finding new sources of energy due to expanding world population, depletion of energy resources, and growing environmental concerns; but there is no question that similar patterns have been in evidence for thousands of years. And there is something timeless and circular about modern society growing crops that once would have been considered food, but now are solely intended to produce energy as biofuels.

When asked to think about energy, most people imagine a light going on in a house or driving a car (Braun et al., 2014). Certainly both of these activities require energy. But where does that energy come from? What source(s) was it derived from? How was it transported to the consumer? How does our energy usage affect the world around us? These are all important questions that require some knowledge about energy systems and sources to answer. As citizens, we have a responsibility to be able to rationally discuss energy-related topics.

Before we dive into energy-related terminology, let us take a look at where we, as a species, should be heading in terms of energy systems. We need more sustainable energy systems. 'Sustainability' - to borrow Thiele’s working definition, which draws on science and ethics-'satisfies meeting current needs without sacrificing future well-being through the balanced pursuit of ecological health, economic welfare, social empowerment, and cultural creativity'. We currently get most of our energy by mining solar energy captured eons ago by photosynthesis and stored as coal, oil, and natural gas in rock formations. It will take millions of years to produce new resources of this type, although we will not run out of oil or natural gas anytime soon, as we discuss in the chapter on fossil fuels. The carbon stored in these 'fossil' fuels is being released into the atmosphere, which is driving climate change. Climate change in turn will increasingly disrupt human activities, requiring us to expend more and more energy and resources just to maintain our current lifestyle. It would be preferable, and cheaper in the long run, to reduce carbon emissions gradually over the next several decades.

It almost goes without saying that nations whichfind themselves blessed by the fates with substantial deposits of extremely desired and, thus, highly valuable natural resources often encounter great difficulty in managing their exploitation and handling thefinancial benefits that flow from tap ping that bounty (Zedalis, 2009). Even among nations that are seeming exceptions to that general proposition, the past makes clear that only great abuse and struggle have helped them evolve to wiser ways. To a certain extent, nature almost does a country a favor in withholding her largesse and compelling its people to scratch a living from the bare bones of their own ingenuity and determination. Virtually every one cognizant of the ways of the world is familiar with how many natural resource rich nations seem to translate raw mineral wealth into exploitation incompetence, sheer ruling-class orruling-family greed, or political despotism and entailed perpetual power.

One way of looking at human development is in terms of the choices and opportunities available to individuals (Ottinger et al., 2005). Energy can dramatically widen these choices. Simply harnessing oxen, for example, multiplied the power available to a human being by a factor of 10 . The invention of the vertical water wheel increased productivity by another factor of 6 ; the steam engine increased it by yet another order of magnitude. The use of motor vehicles greatly reduced journey times and expanded human ability to transport goods to markets.

Today, the ready availability of plentiful, affordable energy allows many people to enjoy unprecedented comfort, mobility, and productivity. In industrialised countries people use more than 100 times as much energy, on a per capita basis, as humans did before they learned to exploit the energy potential of fire.

Although energy fuels economic growth, and is therefore a key concern for all countries, access to and use of energy vary widely among them, as well as between the rich and poor within each country. In fact, 2 billion people - one-third of the world's population - rely almost completely on traditional energy sources and so are not able to take advantage of the opportunities made possible by modern forms of energy. Moreover, most current energy 
generation and use are accompanied by environmental impacts at local, regional, and global levels that threaten human well-being now and well into the future.

Energy produced and used in ways that support human development over the long term, in all its social, economic, and environmental dimensions, is what is meant in this report by the term sustainable energy. Inother words, this term does not refer simply to a continuing supply of energy, but to the production and use of energy resources in ways that promote —or at least are compatible with-long-term human well-being and ecological balance.

An energy system is made up of an energy supply sector and energy end-use technologies. The object of the energy system is to deliver to consumers the benfits that energy offers. The term energy services is used to describe these benefits, which in households include illumination, cooked food, comfortable indoor temperatures, refrigeration, and transportation. Energy servicesare also required for virtually every commercial and industrial activity. For instance, heating and cooling are needed for many industrial processes, motive power is needed for agriculture, and electricity is needed for telecommunications and electronics.

The energy chain that delivers these services begins with the collection or extraction of primary energy that,in one or several steps, may be converted into energy carriers, such as electricity or diesel oil, that are suitable for end uses. Energy end-use equipment—stoves, light bulbs, vehicles, machinery-converts final energy into useful energy, which provides the desired benefits: the energy services. An example of an energy chain-beginning with coal extraction from a mine (primary energy) and ending with produced steel as an energy service.

Energy services are the result of a combination of various technologies, infrastructure (capital), labour (know-how), materials, and primary energy. Each of these inputs carries a price tag, and they are partly substitutable for one another. From the consumer's perspective, the important issues are the economic value or utility derived from the services. Consumers are often unaware of the upstream activities required to produce energy services.

Energy resources are essential for social and economic development, as well as for the everyday life of a human being (Xi et al., 2005). They are part of the physical basis for human survival and constitute a critical pillar for the development of modern industry. The whole process of human civilization has been witness to the development and usage of energy resources. Per capita measures of energy resources, energy ef ficiency, and the environmental impacts of energy production and usage are some of the important indicators for assessing a country's level of modernization. Nowadays, the overdevelopment and consequent overuse of energy resources is one of the primary causes of many types of environmental problems. Maintaining a balance between the development and use of energy resources while simultaneously protecting the environment and ecological systems is a global problem. The establishment of a sustainable energy system, crucial for sustainable development, has been identified as a top priority for many countries. Sustainable development refers to development that meets "the needs of present generations without compromising the ability of future generations to meet their own needs". As such, it requires the utilization of natural resources in a sustainable way. Law plays an important role in establishing such a sustainable energy system.

\section{Energy in Everyday Use}

All people in the world use energy every day for their different needs. How it looks in practice, it best describes Harold H. Schobert who says: Consider the beginning of a typical day (Schobert, 2014). As we get out of bed, we are probably concerned with whether we feel warm enough, with turning on lights so we can see, and with cooking something for breakfast.

These activities all require energy. Many of us live in homes with electric heating; if not, heat is provided by burning a fuel such as natural gas or heating oil. Most people rely on electricity for lighting, but without electricity, the flames of wax candles or kerosene lamps provide illumination. Electric stoves or electric microwave ovens are popular for cooking; so are stoves that use fuels such as wood, coal, or natural gas. Cooking breakfast means that we have to have something to cook. In many parts of the world, few people subsist entirely on what they can raise or catch themselves. Having food available first requires planting, cultivating, and harvesting on farms. Many farmers use a variety of agricultural machinery that operates with gasoline or diesel fuel, and others rely on using animals that require their own food sources. Harvested food has to be transported to facilities where it is processed, prepared, and packaged. Various sources of energy might be used in the processing of foods, including electricity, natural gas, or heating oil. Then the packaged food is transported to warehouses and stores for sale to us, the consumers. Transportation from farm to processing facility and then to stores might require gasoline or diesel fuel.

As we dress and begin to go about our daily routine, we depend on a huge variety of manufactured articles. Very, very few of us weave our own cloth, turn logs into boards to make wooden articles, or make any of the other items we use throughout the day. Manufacturing begins with the production of raw materials, such as producing metals from 
their ores. Many kinds of energy might be used in such operations, including electricity, heating oil, or coal. Then the raw materials must be fabricated into useful articles. Fabrication might involve cutting, casting, machining, or weaving (as but a few examples). Many of these operations use electrically powered machinery, and coal, heating oil, or natural gas as heat sources. Then the manufactured articles must be transported to stores.

Many people in the industrialized world are able to surround themselves with electrical appliances and gadgets: television set, microwave oven, music system, personal computer, electric razor, hair dryer, refrigerator, lamps, coffee maker, electric clock, electric pencil sharpener, electric tooth brush, power tools, and radio — and, for some of these items, often more than one of each. In the kitchen, for example, one can expect to find a stove, a refrigerator, a dishwasher, and a microwave oven. What else? A coffee maker, espresso machine, electric can opener, pasta maker, bread maker, slow cooker, electric carving knife, toaster or toaster oven (or both), and a blender or food processor. No one worries about whether or not there will be enough electricity to operate these gadgets. If there's a problem, it's how to find counter space to use all this stuff or cabinet space to store it.

\section{Energy Law}

The energy sector is, in the production sense, one of the most important factors of any modern society. Given that it forms energy forms that have different phases of production and distribution to the final consumer, the energy sector has become an area which needs to be legally regulated. So it was a new discipline within in law like science discipline which are called the Energy law.

Energy law concerns the management of energy resources (Heffron, 2015). This is a simple definition, and disguises that it is arguably one of the more complex areas of law. It demands that a scholar in the area engage with other disciplines to some degree, such as politics, economics, geography, environmental sciences and engineering.

In 2015, energy law is still considered a new area of law. It appears not to have the established academic literature base of other legal areas. However, this is to misunderstand what energy law is. It has been in existence in different forms for over a century. In the 1800s and early 1900s, there was legislation to manage energy sectors such as coal and oil. These energy sources are known as fossil fuels (along with gas) and form one of the two main categories of energy sources. The other category is low-carbon energy sources which have been in development since after the Second World War (1945) and consist of nuclear energy, hydropower, wind, solar, biomass and several other minor renewable energy sources.

Energy law has now come to the fore. It is viewed with a holistic approach today whereas before it was divided into many parts - in general in terms of each type of energy source. There is a realisation in the twenty-first century of the fundamental role that the energy sector plays in the economy of acountry. It is an important sector for employment, future economic development and the personal health of a nation's citizens. In particular, it has been pushed high up the political agenda with the advent of climate change and policies concerning energy security. For example, the impacts of Russia's ability to affect gas prices in the majority of the European Union (EU) have highlighted the importance of the energy sector at both EU and Member State level. Further, politicians can be credited with pushing the agenda, in part, because high energy prices - mainly electricity prices - have an influence on election outcomes.

Although public international law has existed for many centuries, it is only since the1970s that it has concerned itself with energy issues (Lyster et al., 2006). Traditionally the legal regulation of energy issues has been regarded as a matter of domestic, rather than international law, and a matter that is exclusively for the States to resolve on an individual basis. This traditional approach has changed for a variety of reasons, largely involving international trade. First and foremost, there has been an exponential leap in the quantum of energy use worldwide, particularly in developed countries, since the end of the Second World War. This has led to increased energy trade and increased reliance in many countries on energy imports, particularly petroleum products, which in turn has led to heightened energy security concerns. These concerns were brought to world attention by the Arab oil embargo in 1973 and the subsequent oil price increases in 1979 and 1981. Although the only direct legal consequence flowing from the Organisation of Petroleum Exporting Countries' (OPEC) strangle hold on petroleum exports was the agreement to create a strategic petroleum reserve, to guard against future world export problems, the OPEC ascendancy in the 1970s was responsible for highlighting energy security concerns worldwide and caused many countries to rethink their energy strategies.

The development of free trade principles under the GATT (General Agreement on Tariffs and Trade) and the creation of regional and bilateral free trade agreements also have significant implications for international energy markets. In relation to regional energy markets, the European Union is creating an internal energy market and a 
corresponding harmonisation of the energy laws of the member nations. The North American Free Trade Agreement (NAFTA), which is now as far-reaching in this regard as the European Union's single energy market, entails a restriction on the sovereign rights of individual members to enact energy laws inconsistent with the freedom to trade across borders in the energy field.

\section{Energy Policy}

The modern lifestyle involves increasing use of energy in order to achieve increasing efficiency and comfort and energy use is growing every day (Franjić, 2015). Today, most of the energy needs of mankind settled using very harmful fossil fuels, and in the future will be the fuel to be replaced with cleaner sources of energy in the form of renewable energy sources or nuclear power. In the future, renewable energy sources will become the primary, and the energy needs of humanity will get bigger. That modern style of life have intention to be important part of strategy of economic development.

Increasing energy import dependency and limited success in achieving diversification, high and fluctuating energy prices, growing demand, security risks associated with transport routes, climate change, the need to liberalize the energy market, limited coordination factors of energy policy that impedes investment in energy infrastructure and difficulties on the market of oil and gas are just some of the important issues the EU was faced with over time, and the same led to the necessity of creating a common European energy strategy (Franjić, 2016).

In times of increasing environmental and climate challenges or diplomatic crises, energy issues have repeatedly entered the agendas of policy makers, researchers and society in the European Union under a number of different frames (Biesenbender, 2015). During the last 60 years, EU environmental policy has taken place under changing institutional, environmental and societal conditions. These conditions have influenced both agenda shaping and decision making with regard to the regulation of energy issues. During the first decades of the European integration process, the main motivation was to secure energy provision in an emerging community of nation-states. Moreover, in the 1960s, 1970s and 1980s, several attempts were made to design a comprehensive energy policy and to transfer national capacities with regard to energy security to the EU-a topic that has recently gained renewed attention. However, in the absence of any concrete primary law to empower the EU institutions to regulate the energy sectors prior to the mid-1980s, these attempts failed because they did not reach consensus among the member states. Finally in the 1990s, the EU was successful in liberalising the electricity market. However, despite its implications for the common market, energy policy was not defined as an area of priority action by primary (i.e. treaty) law until the passage of the Treaty of Lisbon. Since then, energy policy has ranked high on the EU's political agenda, which has also led to the passage of concrete regulatory decisions. This process was also motivated and shaped by concerns for environmental and climate change. In addition, the mid- and long-term security of energy supplies has been a main driver of the EU's energy policy agenda.

Altogether, the emergence of EU energy policy decisions and their agenda shaping processes have been strongly linked to developments in the international energy markets, the evolution of EU primary law, national policy targets and decisions as well as developments in the environment and climate. Changes in treaty law and problem perception along with new framing opportunities have therefore paved the way for the development of a comprehensive energy policy since the mid-2000s. Shortly thereafter, regulations were passed to extend the agenda-shaping power of the European public through the introduction of the European Citizens' Initiative thereby laying the legal foundations for a smooth interaction between the systemic and the EU's political agendas.

Energy policy in many EU countries has recently focused on the expansion of RES (Renewable Generation Sources) (Perner et al., 2015). Non-dispatchable technologies18 of wind and solar play a particular role in this. Therefore, RES expansion can raise particular issues in relation to future security of supply especially in relation to (a) volatility of generation and (b) inaccuracies of production forecast.

In relation to (a), volatile and fluctuating generation from wind and solar requires the availability of secured back-up capacities through storage, conventional generation, or demand flexibility that can step in for these renewables. The question is whether market mechanisms alone can deliver these capacities. In relation to (b) inaccuracies in production forecast, the availability of wind and solar radiation can only be predicted with limited accuracy. The availability of respective plants is only known with high certainty shortly (a few hours or less) before real-time dispatch. This holds even though there have been significant improvements in forecasting accuracy in recent years. This uncertainty about actual production requires back-up capacity that needs to be dispatchable at short notice. 


\section{Energy Poverty}

Energy is the main strategic resource in developed countries (Franjić, 2018.). It has a huge impact on the quality of daily life and every day more and more benefits. It also has a huge impact on the entire social infrastructure and thus is inextricably linked to the growth and development of the economy. However, the economic crisis took its toll, which means that many people have lost their jobs but their opportunities for energy consumption significantly reduced. Energy richness is a proof of modern trends in production, which means that there is also the energy that is produced, for example, through the wind power system and through biological systems. Given the financial situation in which they are, people are not currently able to pay any extra costs or energy.

Energy poverty occurs when a household is unable to secure a level and quality of domestic energy services - space cooling and heating, cooking, appliances, information technology—sufficient for its social and material needs (Bouzarovski, 2018.). This somewhat contested and broad definition lies at the tip of a vast scientific and policy iceberg, involving complex socio-technical relations that extend across the planet. Energy poverty affects millions of people worldwide, even if the causes and consequences vary depending on context. Historically, the existence of this condition in the Global North has been attributed to contingencies such as low incomes, energy-inefficient homes and high energy prices, while in the Global South, the infrastructural lack of access to more technologically advanced energy carriers has been seen as the main culprit. It is estimated that more than one billion people across the world suffer from this condition; and it has received significant prominence thanks to high-profile international drives such as the 'Sustainable Energy for All' initiative, aimed at 'reducing the carbon intensity of energy while making it available to everyone on the planet' so as to contribute to a 'cleaner, just and prosperous world for all'.

Energy poverty-lack of access to electricity and dependence on solid biomass fuels for cooking and heating-remains an enduring global problem (Sovacool et al., 2018). Approximately 1.4 billion people still live without electricity, and an additional 2.7 billion people depend entirely on wood, charcoal, and dung for their domestic energy needs. Lack of access to modern energy not only limits opportunities for income generation and blunts efforts to escape poverty, it also severely impacts women and children and contributes to global deforestation and climate change. The search for energy fuels and services is therefore an arduous, daily grind for billions of people around the world, most of them in Asia, where serious repercussions of energy poverty assume different forms depending on geographical terrain, population size, and climatic variations.

However, small-scale renewable energy technologies-solar home systems, residential wind turbines, biogas digesters and gasifiers, microhydro dams, and improved cookstoves — offer these households and communities the ability to tackle extreme poverty, enhance gender equality and education, reduce hunger, provide safe drinking water, improve health, and ensure environmental sustainability. Innovative collaborations and programs involving governments as well as businesses, nonprofit organizations, banks, and community based cooperatives have emerged in recent years to expand access to these technologies and the energy services they offer. All over Asia, these burgeoning partnerships have come in different forms: some focus on improving technological performance, others on providing low-cost loans, still others leasing out systems according to a "fee-for-service" model. But regardless of their approach, such technologies and the programs that support them can drastically improve living standards for some of the poorest communities in the region.

\section{Conclusion}

The main goal in planning the energy development of each country is to create such an energy system that would be independent of energy imports and have minimal costs and losses in production, conversion, transmission, distribution and transportation. In doing so, special attention must be paid to the conversion of primary forms of energy into secondary and used forms, bearing in mind the costs of preserving a healthy environment. Energy production is extremely important today. The need for energy belongs to the same group as the production of food and raw materials and the provision of the required amounts of water. Energy supply is a prerequisite for economic development as well as for the growth of living standards. In addition, the development of energy has an impact on a many economic branches, which is why the development of energy is inextricably linked with the development of the economy. 


\section{References}

Biesenbender, S. (2015). “The EU’s Energy Policy Agenda: Directions and Developments”. In Tosun, J., Biesenbender, S., Schulze, K. (eds.), "Energy Policy Making in the EU-Building the Agenda”, Springer-Verlag, London, UK, 2015, pp. 21-22.

Bouzarovski, S. (2018). “Energy Poverty-(Dis)Assembling Europe's Infrastructural Divide”. Palgrave Macmillan, Springer International Publishing AG, Cham, Switzerland, pp. 1-2.

Braun, T. F., Glidden, L. M. (2014). “Understanding Energy And Energy Policy”, Zed Books, London, UK, p. 12.

Coyle, E. D., Grimson, W., Basu, B., Murphy, M. (2014). "Reflections on Energy, Greenhouse Gases, and Carbonaceous Fuels”, in Coyle, E. D., Simmons, R. A. (eds.): “Understanding the Global Energy Crisis”, Purdue University Press, West Lafayette, USA, p. 12.

Franjić, S. (2015). “Croatian Strategy of Energy Development, European Union, Climate Change and the Environment Protection”, Journal of Energy and Power Sources, Vol. 2, No. 7, Rowland Heights, USA, July 2015., pp. 268-273.

Franjić, S. (2016). "Legal Regulations of European Energy Policy in Croatia”, Applied Engineering Letters, Novi Sad, Serbia, Vol. 1, No. 2, pp. 40-45.

Franjić, S. (2018). "Energy Poverty in Croatia", 7. Međunarodni znanstveni simpozij "Gospodarstvo istočne Hrvatske vizija i razvoj” / 7th International Scientific Symposium "Economy of eastern Croatia-vision and growth”, Sveučilište Josipa Jurja Strossmayera u Osijeku, Ekonomski fakultet u Osijeku, May 24th-26th, 2018, Osijek, Croatia, pp. 528-536.

Heffron, R. J. (2015). “Energy Law_An Introduction”, Springer International Publishing, Cham, Switzerland, p. 1.

Lyster, R., Bradbrook, A. (2006). “Energy Law and the Environment”, Cambridge University Press, Cambridge, UK, pp. 34-35.

Perner, J., Riechmann, C. (2015). “Energy Market Design with Capacity Mechanisms”, in Hancher, L., De Hautecloque, A., Sadowska, M. (eds.): “Capacity Mechanisms in EU Energy Markets-Law, Policy, and Economics”, Oxford University Press, Oxford, UK, 2015, p. 72.

Schobert, H. H. (2014). “Energy And Society-An Introduction, Second Edition”, CRC Press, Taylor \& Francis Group, Boca Raton, USA, pp. 1-2.

Sovacool, B. K., Drupady, I. M. (2012). "Energy Access, Poverty, and Development—The Governance of Small-Scale Renewable Energy in Developing Asia”, Ashgate Publishing Limited, Farnham, UK, p. 1.

World Energy Assessment: United Nations Development Programme, United Nations Department of Economic and Social Affairs, World Energy Council, World Energy Assessment and the Challenge of Sustainability. (2000). "In Ottinger, R. L., Robinson, N., Tafur, V. (eds.) (2005): “Compendium of Sustainable Energy Laws”, Cambridge University Press, Cambridge, UK, pp. 1-3.

Xi, W., Runlin, M., Dong, M. (2005). “Strategy, Policy, and Law Promoting Renewable Energy Resources in China”, in Bradbrook, Adrian J., Lyster, Rosemary, Ottinger, Richard L., Xi, Wang (eds.): “The Law of Energy for Sustainable Development”, Cambridge University Press, Cambridge, UK, p. 302.

Zedalis, R. J. (2009). “The Legal Dimensions of Oil and Gas In Iraq-Current Reality and Future Prospects”, Cambridge University Press, New York, USA, p. 138. 